European journal of American studies

\title{
Barack Obama's Dreams from My Father and African American Literature
}

Daniel Stein

\section{(2) OpenEdition}

Journals

Electronic version

URL: https://journals.openedition.org/ejas/9232

DOI: $10.4000 /$ ejas. 9232

ISSN: 1991-9336

Publisher

European Association for American Studies

\section{Electronic reference}

Daniel Stein, "Barack Obama's Dreams from My Father and African American Literature", European journal of American studies [Online], 6-1 | 2011, document 6, Online since 16 September 2011

connection on 08 July 2021. URL: http://journals.openedition.org/ejas/9232 ; DOI: https://doi.org/ 10.4000/ejas.9232

This text was automatically generated on 8 July 2021.

Creative Commons License 


\title{
Barack Obama's Dreams from My Father and African American Literature
}

\author{
Daniel Stein
}

\section{The Arc of History}

1 Shortly after Barack Obama had been elected the first African American president of the prestigious Harvard Law Review in 1990, Times Books approached him with the request for an autobiography that would tell the story of his success as a black professional and academic. Obama took time off from his work as a lawyer and wrote Dreams from My Father: A Story of Race and Inheritance, published in 1995. The reviews, as he notes in the introduction to the second edition, "were mildly favorable," but "sales were underwhelming" (vii). Today, this is a different story. Reprinted in 2004 and boosted by Obama's speech at the Democratic National Convention in Boston, Dreams from My Father quickly climbed to the top of the New York Times bestseller list and sold millions of copies. It was followed two years later by The Audacity of Hope (2006), in which Obama formulated his thoughts on what he called "reclaiming the American dream" and which launched his successful presidential campaign.

Speaking in Chicago only hours after having been elected the 44th president of the United States, Obama reflected on the significance of this event and, in doing so, evoked a black woman named Ann Nixon Cooper. This 106-year-old woman, Obama noted, had seen America change from a segregated nation in the early decades of the twentieth century to a nation willing to elect a black American as its president in the twenty-first. Recalling Cooper's lifespan, Obama re-cast his campaign slogan "Yes we can" as "that American creed" and walked his audience through the touchstones of twentieth-century history: the women's suffrage movement, the Great Depression, the New Deal, Pearl Harbor, World War II. He further connected his personal story with one of America's most emotional moments and figures in recent history: the struggles of 
the civil rights movement and Martin Luther King. About Ann Nixon Cooper's life in the 1950s and 60s, Obama said: "She was there for the busses in Montgomery, the hoses in Birmingham, a bridge in Selma, and a preacher from Atlanta who told a people that "We Shall Overcome"' ("Remarks" 322-23).

Those familiar with Obama's speeches and writings, especially his remarks on race in a speech he had delivered at the Convention Center in Philadelphia earlier in the year ("A More Perfect Union"), must have recognized this rhetorical gesture as Obama's attempt to write himself into a prominent narrative of American history and come to terms with the role that race has played in this narrative. ${ }^{1}$ What the majority of his listeners probably did not recognize was the literary source that most likely motivated this gesture: Ernest J. Gaines's fictional Autobiography of Miss Jane Pittman (1971), a "neoslave narrative" (Ashraf Rushdy's term) which tells the story of the 110-year-old narrator, Miss Jane Pittman. This woman was born a slave in the 1850s, struggled her way through the civil war, looked forward to a brighter future during the era of Reconstruction, endured the setbacks of the Jim Crow system, and, toward the end of her life, witnessed civil rights marches and the rise of black militancy.

Miss Jane Pittman's story speaks to an understanding of history that Ralph Ellison likened to a boomerang in Invisible Man (1952): “[0]ur whole culture," Invisible Man muses, does not move "like an arrow, but [like] a boomerang. (Beware of those who speak of the spiral of history; they are preparing a boomerang. Keep a steel helmet ready)" (5). Yet the mere fact that Obama offered his thoughts as president-elect and not from an underground shelter on the outskirts of Harlem is reason enough to view Ellison's remarks in a new context. According to the historical trajectory Obama had outlined in his speech on race, the election of an African American to the presidency may be understood as a major step toward fulfilling the promises of the U.S. Constitution. "The document they [the founding fathers] produced was eventually signed but ultimately unfinished," Obama had argued: "It was stained by this nation's original sin of slavery" and had, in the centuries to follow, seen generation after generation take part in "the long march ... for a more just, more equal, more free, more caring and more prosperous America" ("A More Perfect Union" 255-56).

Martin Luther King's "I Have a Dream" (1963) is the obvious subtext here, especially King's metaphor of the check with insufficient funds written by the founding fathers. ${ }^{2}$ But Obama's victory speech also contained an implicit reference to Invisible Man. His election to the presidency, Obama alleged, was "the answer that led those who have been told for so long by so many to be cynical, and fearful, and doubtful of what we can achieve to put their hands on the arc of history and bend it once more toward the hope of a better day" (emphasis added). Obama's election victory, this statement implies, rewrites American history because it reveals Ellison's boomerang analogy as a dated concept. ${ }^{3}$ Thus, Obama aims to revise Ellison's modernist doubts and the alienation of his narrator by claiming a new sense of trust in the collective future of the country and by suggesting that the boomerang of history (the notion that there always have been and always will be setbacks) can be bent into an arc of progress (transcendence of racism without denying the significance of race). ${ }^{4}$

Obama's victory speech elaborates on a concept he had already introduced in Dreams from My Father and The Audacity of Hope: the willingness to hope for a better future as personal need and national creed, as a bulwark against pessimism and doubt. This concept is rooted in the theology of his former pastor Reverend Jeremiah Wright and 
derives its name from a sermon Obama heard at Wright's Trinity United Church of Christ in Chicago. This sermon initiated Obama's conversion experience, according to Dreams from My Father. Hearing the Reverend preach, Obama realized that these biblical "stories-of survival, and freedom, and hope-became our story, my story," that "[o]ur trials and triumphs became at once unique and universal, black and more than black," and that "I also felt for the first time how that spirit carried within it, nascent, incomplete, the possibility of moving beyond our narrow dreams" (294). ${ }^{5}$ This audacity of hope for a better future against the odds and the belief in America's arc of history may prove to be lasting contributions to American political and literary discourse, the roots of which trace back to Frederick Douglass's angry complaints in "What, to the Slave, Is the Fourth of July?" (1852), Booker T. Washington's concession of 1895 that "[i]n all things that are purely social, we can be separate as the fingers, yet one as the hand in all things essential to mutual progress" (83), and the fundamental question which W.E.B. Du Bois denounced in The Souls of Black Folk (1903): "How does it feel to be problem?" (101). ${ }^{6}$

7 Obama's overt references to Martin Luther King, his covert references to Gaines's and Ellison's novels, and the expansive scope of his remarks suggest an intimate knowledge of African American rhetorical, literary, and intellectual traditions. ${ }^{7}$ I believe that Obama's use of these traditions neither constitutes a "rejection of his "whiteness" nor a "Kierkegaardian leap into blackness," as David Samuels argues in his enlightening but frequently troubling piece for the New Republic ("Invisible Man"). Rather, these sources enable Obama, "a black man with a funny name" (Dreams viii), to create a public story of his life by working through some of the most influential African American conceptualizations of self and society: double consciousness, racial invisibility, and black nationalism. ${ }^{8}$ Dreams from My Father depicts what Ron Walters has called "the story of his journey into functional Blackness" (8), and one does not have to be naïve to assume that this journey is not premised on the "old-fashioned, unabashedly romantic and ... quite weird idea of racial authenticity" (Samuels, "Invisible Man") but follows from a keen understanding of the powers and limitations of race in American political, cultural, and literary history. ${ }^{9}$

\section{Autobiography, Memoir, Family History, or Something Else}

8 The title of Obama's autobiography, Dreams from My Father,announces an intergenerational perspective that involves both a passing on of dreams from father to son and the son's search for his father's past. This double perspective is emphasized further by the subtitle, A Story of Race and Inheritance, which connects Obama's search for his Kenyan father, who left the family when his son was two years old, whom Obama only saw once for a few weeks when he was ten, and who died when Obama was twenty-one, with the search for a viable narrative of his life, for a way to make sense of his transatlantic heritage..$^{10}$ Integral elements of this search are core themes of African American letters: the quest for self-discovery vis-à-vis social constructions of race; the search for ancestors, the meanings of home, and the power of dreams in the struggle for racial equality. In the words of Cornel West: "What is my relation to my African heritage ...? How do I understand my African American tradition and sense of homelessness in America?" (x). ${ }^{11}$ 
In his introduction to the 1995 edition, Obama establishes a connection between his unusual life story and the complex generic status of his narrative as "autobiography, memoir, family history, or something else" (xvii). Categories and labels, it seems, are always applied by others and rarely describe an inside experience: "Whatever the label that attaches to this book-... what I've tried to do is write an honest account of a particular province of my life" (xvii). His story, Obama writes, differs from what he considers the typical autobiography or memoir; the book is "a record of a personal, interior journey-a boy's search for his father, and through that search a workable meaning for his life as a black American." He continues:

An autobiography promises feats worthy of record, conversations with famous people, a central role in important events. There is none of that here. At the very least, an autobiography implies a summing up, a certain closure, that hardly suits someone of my years, still busy charting his way through the world. I can't even hold up my experience as being somehow representative of the black American experience. (xvi)

This passage foregrounds an awareness of personal writing as an act of self-creation. "He, too, will have to invent himself" (428), Obama writes about his father as a young boy dreaming of living in America, but he might just as well be talking about himself. The modern black intellectual, as Ross Posnock suggests, is a public figure in American life rarely found but more often made (cf. 1-2); "blackness" is something to be achieved, and not simply inherited, as Algernon Austin has illustrated. ${ }^{12}$

11 The project of making his life meaningful moves Obama towards a pernicious problem: the problem of race, which Du Bois announced would be the problem of the twentieth century (cf. Souls 100) and which has shaped African American literature from its inception. Obama's life story may not be "representative of the black American experience," but it must come to terms with this historical experience-and especially the literature that has voiced the many and often contradictory facets of this experience-if the narrator is to make sense of his own experience. This applies to Dreams from My Father as well as to Obama's later presentations of his life story, for instance in his speech at the Democratic National Convention in 2004. Here, he sought to establish a connection between his family history and American slavery by crediting his grandfather, whom he described as "a cook, a domestic servant to the British," with having "larger dreams" for his son, Obama's father ("Keynote" 98). In the context of the debates over Obama's "blackness"-whether he was "black enough" or "too black" for a presidential candidate-the reference to his grandfather's life as a servant is important because it allows him to claim a family history of servitude even though he has no slave ancestors. Stanley Crouch, for instance, writing in the New York Daily News ("What Obama Isn't: Black like Me"),harped on the fact that Obama "does not share a heritage with the majority of black Americans, who are descendants of plantation slaves." ${ }^{13}$ Yet it is the birth of "black" literary selves and the willingness to speak autobiographically that has driven African American literature since the early days of the slave narratives, and it is Obama's self-conscious investment with African American literature that allows him to propose a more nuanced understanding of racial belonging than Crouch and others have advocated. ${ }^{14}$ 


\title{
3. I Had No Idea Who My Own Self Was
}

12 Feelings of alienation lead the young Obama to a place frequently depicted in black autobiographies: the library as a source of personal enlightenment and intellectual growth. Two prominent examples areRichard Wright's Black Boy of 1945, where the narrator describes an endless hunger for books (cf. 220-21), and Alex Haley's The Autobiography of Malcolm X of 1965, where Malcolm X recalls how "reading had changed forever the course of my life" (180) and states "that my alma mater was books, a good library" (181). Obama is struggling to understand the implications of being perceived as black in an almost all-white school (and, since his father is absent, in an all-white family): "I was different, after all, potentially suspect," he writes; "I had no idea who my own self was" (82). He turns to the classics of African American literature in order to find solutions to his problems: W.E.B. Du Bois's Souls of Black Folk, Richard Wright's Native Son (1940), Ralph Ellison's Invisible Man, as well as writings ofLangston Hughes and James Baldwin. ${ }^{15}$ As the narrator describes the situation:

\begin{abstract}
At night I would close the door to my room, telling my grandparents I had homework to do, and there I would sit and wrestle with words, locked in suddenly desperate argument, trying to reconcile the world as I'd found it with the terms of my birth. But there was no escape to be had. In every page of every book, in Bigger Thomas and invisible men, I kept finding the same anguish, the same doubt; a selfcontempt that neither irony nor intellect seemed able to deflect. Even DuBois's learning and Baldwin's love and Langston's humor eventually succumbed to its corrosive force, each man finally forced to doubt art's redemptive power, each man finally forced to withdraw, one to Africa, one to Europe, one deeper into the bowels of Harlem. (85-86) ${ }^{16}$
\end{abstract}

Thus, while Obama appreciates the literature on an aesthetic level, and while he recognizes its emotional urgency, he is unable to fit his own experience into this tradition because it focuses too much on the problems of race (anguish, self doubt, selfcontempt, withdrawal), and not enough on potential solutions (its redemptive power as well as hopes and dreams). ${ }^{17}$

The text to which Dreams from My Father relates most explicitly is The Autobiography of Malcolm X. It is here that the youthful obama finds at least temporary answers: "Only Malcolm X's autobiography seemed to offer something different. His repeated acts of self-creation spoke to me; the blunt poetry of his words, his unadorned insistence on respect, promised a new and uncompromising order" (86). Yet even this autobiography, with its scenes of hipster life, its revolutionary rhetoric, and its spiritual ending, ultimately leaves him unsatisfied. Obama's initial appreciation and eventual dismissal of The Autobiography of Malcolm Xmake sense because they allow him to claim the text as part of his literary ancestry while simultaneously providing him with a foil against which he can establish his post-black-nationalist position on race. This functional stance also informs his characterization of a Kwame Touré's (Stokely Carmichael) appearance at Columbia University as "a bad dream" (140). ${ }^{18}$

Malcolm X's racially derisive rhetoric is troubling: Malcolm "spoke of a wish he'd once had, the wish that the white blood that ran through him, there by an act of violence, might somehow be expunged. I knew that, for Malcolm, that wish would never be incidental. I knew as well that traveling down the road to self-respect my own white blood would never recede into mere abstraction" (86). ${ }^{19}$ This, then, is where the revolutionary powers of black autobiography reveal their limits, at least according to 
Obama's functional reading. ${ }^{20}$ For Malcolm X, his white blood signifies a history of violence, rape, and enslavement, but, as Obama points out, it lacks a concrete referent: The white man who raped his mother remains an abstraction, however emotionally charged, because Malcolm X has no personal knowledge of him. The circumstances of Obama's mixed racial heritage, on the contrary, are much more concrete. The brief love story of his mother, a young white college student from Kansas, and his father, the first black African student admitted to the University of Hawaii, inspires Obama to speak with personal knowledge of racial reconciliation. ${ }^{21}$ David Samuels speaks of "Obama's rejection of his "white blood" and the "exclusion" of his white mother from the narrative, but I believe that Obama's focus on his black father-he neither excludes nor rejects his mother-can be explained by the fact that the long history of African American literary and intellectual engagements with questions of self and society has more to contribute to the project of developing a workable life story than his mother's Midwestern heritage..$^{22}$ Moreover, Obama is very explicit about the legal implications of his parents' relationship. "Miscegenation. The word is humpbacked, ugly, portending a monstrous outcome: like antebellum or octoroon, it evokes images of another era, a distant world of horsewhips and flames, dead magnolias and crumbling porticos" he writes, noting that the marriage between a white and a black person was "still described a felony in over half the states in the Union" in 1960 (11-12).

Reading Malcolm X, Obama recognizes the powerful ideals of black nationalism but criticizes its insistence on racial division. He writes: "Ever since the first time I'd picked up Malcolm X's autobiography, I had tried to untangle the twin strands of black nationalism, arguing that nationalism's affirmative message-of solidarity and selfreliance, discipline and communal responsibility-need not depend on hatred of whites" (197). Most detrimental, according to Dreams from My Father, is the discrepancy between the idealism of black nationalism and the actual problems in Chicago's black neighborhoods. Obama contrasts the "morality of subtle distinctions" his mother had taught him (199) with the "unambiguous morality tale" provided by the nationalists, a morality tale "easily communicated and easily grasped" and aimed almost exclusively against "the white race" (198). It is not the message of solidarity and self-reliance, discipline and communal responsibility that causes problems, but the pragmatic inflexibility and subsequent sociopolitical failures of this cultural model. Obama thus wonders whether "nationalism could deliver" and identifies "questions of effectiveness, and not sentiment" as well as "the distance between our talk and our action" as the cause of his disagreements with the black nationalists $(200,203){ }^{23}$

Obama's complicated position vis-à-vis black history shapes his understanding of African American writing (and vice versa). In the introduction to the 1995 edition, he taps into the evocative power of Ellison's InvisibleMan and Du Bois's Souls of Black Folk while ultimately seeking to move past the racial logic he associates with them:

When people who don't know me well, black or white, discover my background ..., I see the split-second adjustments they have to make, the searching of my eyes for some telltale sign. They no longer know who I am. Privately, they guess at my troubled heart, I suppose-the mixed blood, the divided soul, the ghostly image of the tragic mulatto trapped between two worlds. And if I were to explain that no, the tragedy is not mine, or at least not mine alone, it is yours, sons and daughters of Plymouth Rock and Ellis Island, it is yours, children of Africa, ... it's on the nightly news for all to see, ... well, I suspect that I sound incurably naïve ... Or worse, I sound like I'm trying to hide from myself. (xv) 


\section{though they cannot be reconciled easily. ${ }^{29}$ The way out of this "Du Boisian dilemma"} (Gerald Early's phrase; cf. xvii), out of this "double bind" (Sandra Adell's term), is to recalibrate the equation: Instead of reconciling two thoughts, two strivings, and two ideals in one body-Americans of all colors and creeds must make one out of many ("E pluribus unum") by reconciling many thoughts, many strivings, and many ideals in one body politic. Here, Obama comes full circle from Ellison's prologue (the boomerang analogy) to the novel's epilogue, where the narrator notes: "Our fate is to become one, and yet many" (435)..$^{30}$

\section{We Share More Than Divides Us}

In the epilogue of Dreams from My Father, Obama speaks of the need to find "solutions to the puzzle of being a black man" (442). His autobiography offers one such solution by 
translating the search for racial belonging and ancestral roots into a call for community: "I'll organize black folks," he writes about his commitment to civil rights work and social engagement in words reminiscent of Du Bois (133). This commitment is central in the history of African American thought. It is voiced inMartin Luther King's "I Have a Dream," which includes a line that Obama evoked in his speech at the Ebenezer Baptist Church and his acceptance speech at the Democratic National Convention in 2008: "We cannot walk alone" ("Great Need" 244; "Democratic" 136, 137). In the "Great Need" speech, Obama further spoke of "King's vision of a beloved community" and called for renewed efforts to establish this community. ${ }^{31}$ In Dreams from My Father, this vision and the pledge to contribute to its realization begins with Obama's work as a community organizer in the impoverished South Side of Chicago. Upon leaving for Chicago, he observes:

Whatever my father might say, I knew it was too late to ever truly claim Africa as my home. And if I had come to understand myself as a black American, and was understood as such, that understanding remained unanchored to place. What I needed was a community.... A place where I could put down stakes and test my commitments. (115)

After he has worked as an organizer for a while, he realizes: "There was always a community there if you dug deep enough" (190).

This realization is part of a larger personal development, which had begun with his naiveté after graduating college and gains depth in the streets of Chicago: "[A]bout to graduate from college, I was operating mainly on impulse," he notes,

like a salmon swimming blindly upstream toward the site of his own conception. In classes and seminars, I would dress up these impulses in the slogans and theories I'd discovered in books. (134)

What is missing is a personal connection, and he makes this connection when he visits Africa (like Malcolm X and Baldwin, he has to leave the country of his birth in order to gain a fresh perspective on questions of racial identity and race relations). ${ }^{32}$ This Africa, mainly Kenya, is not an authentic place of tribal community, and it is neither "just like [Alex Haley's] Roots," as Obama's friends in Chicago assume (302). It is a place where "the world was black, and so you were just you; you could discover all those things that were unique to your life without living a lie or committing betrayal" (311). It is also the place where Obama comes to a personal realization at his father's grave (this is the inheritance to which the subtitle refers). In order to gain a sense of communal connection and personal responsibility, people have to recognize the powers of their personal stories and their ties to the stories of others:

I realized that who I was, what I cared about, was no longer just a matter of intellect or obligation, no longer a construct of words. I saw that my life in America-the black life, the white life, the sense of abandonment I'd felt as a boy, the frustration and hope I'd witnessed in Chicago-all of it was connected with this small plot of earth an ocean away, connected by more than the accident of a name or the color of my skin. The pain I felt was my father's pain. My questions were my brothers' questions. Their struggle, my birthright. (430)

26 This basic human connectedness among members of a widely dispersed and fragmented family provides the emotional and philosophical basis for Obama's political vision. In his speech on Martin Luther King Day, he recalled King's allegorical reading of Americans as "all tied together in a single garment of destiny," and in his presidential victory speech, he maintained that "our stories are singular, but our destiny is shared" ("Remarks" 322). Dreams from My Father supplies the personal context 
for this recollection. "[M]y identity might begin with the fact of my race, but it didn't, couldn't, end there," Obama writes, referencing Baldwin's justification for leaving the United States but moving beyond Baldwin's disillusion by acknowledging his personal conviction as a matter of choice, as an attempt to formulate a sense of self based on the notion of "functional Blackness": "At least that's what I would choose to believe" (111). ${ }^{33}$ In other words, rather than embrace the "old-fashioned, unabashedly romantic and ... quite weird idea of racial authenticity," as David Samuels claims, Obama actually proposes an understanding of race that moves beyond the specter of identity politics: personal stories and literary histories are the powerful sources through which a functional sense of self and a political vision can be created.

What his father's youngest brother, Sayid, says about the Nigerian writer Chinua Achebe, motivates Obama to come back home. It rings true for his political message and finds a middle ground between black nationalism, double consciousness, and racial invisibility: "We share more than divides us" (382). From this sense of a common history, a common purpose, emerges one of Obama's most frequently repeated biblical acknowledgements, a modified version of Cain's question to God: "I am my brother's keeper; I am my sister's keeper" (cf. "Great Need" 240; "More Perfect Union" 265; "Democratic" 127). This realization empowers Obama to call on his fellow citizens to "make their claim on this community we call America" and "choose our better history" (439).

\section{BIBLIOGRAPHY}

Abbott, Philip. States of Perfect Freedom: Autobiography and American Political Thought. Amherst: U of Massachusetts P, 1987.

Adell, Sandra. Double-Consciousness/Double Bind: Theoretical Issues in Twentieth-Century Black Literature. Urbana: U of Illinois P, 1994. 56-89.

Andrews, William L. ed. African American Autobiography: A Collection of Critical Essays.

Englewood Cliffs: Prentice-Hall, 1993.

Asante, Molefi Kete. "Barack Obama and the Dilemma of Power: An Afrological Observation."

Journal of Black Studies 38.1 (2007): 105-15.

Atwater, Deborah F. "Senator Barack Obama: The Rhetoric of Hope and the American Dream." Journal of Black Studies 38.2 (2007): 121-29.

Austin, Algernon. Achieving Blackness: Race, Black Nationalism, and Afrocentrism in the Twentieth Century. New York: New York UP, 2006.

Baldwin, James. "The Discovery of What It Means to Be an American." Morrison, Collected Essays. 137-42.

---. "Nobody Knows My Name: A Letter from the South." 1961. Morrison, Collected Essays. 197-208. 
Banita, Georgiana. "'Home Squared': Barack Obama's Transnational Self-Reliance."Biography33.1 (2010): 24-45.

---. "Notes of a Native Son.” 1951. Morrison, Collected Essays. 63-84.

Benstock, Shari, ed. The Private Self: Theory and Practice of Women's Autobiographical Writings. Chapel Hill: U of North Carolina P, 1988.

Callahan, John F., ed. The Collected Essays of Ralph Ellison. New York: Modern Library, 1995.

Chinosole. African Diaspora and Autobiographics: Skeins of Skin and Self. New York: Lang, 2001.

Cone, James H. Martin and Malcolm and America: A Dream or a Nightmare. Maryknoll: Orbis, 1991.

Crouch, Stanley. “What Obama Isn't: Black like Me on Race.” New York Daily News. 2 Nov. 2006. <http://www.nydailynews.com/opinions/2006/11/02/2006-11-02_what_ obama_isnt_black_like_me_on_race.html>.

Daley, James, ed. Great Speeches by African Americans: Frederick Douglass, Sojourner Truth, Dr. Martin Luther King, Jr., Barack Obama, and Others. Mineola: Dover, 2006.

Du Bois, W. E. B. The Souls of Black Folk. 1903. The Oxford W. E. B. Du Bois Reader. Ed. Eric J. Sundquist. New York: Oxford UP, 1996. 97-240.

Dudley, David L. My Father's Shadow: Intergenerational Conflict in African American Men's Autobiography. Philadelphia: U of Pennsylvania P, 1991.

Eakin, Paul John. "Malcolm X and the Limits of Autobiography." Andrews 151-61.

Early, Gerald, ed. Lure and Loathing: Essays on Race, Identity, and the Ambivalence of Assimilation. New York: Lane/Penguin, 1993.

Ellison, Ralph. Invisible Man. 1952. New York: Random, 1982.

---. "The Little Man at Chehaw Station: The American Artist and His Audience." 1977/78. Callahan 489-519.

---. “The World and the Jug." 1964. Callahan 155-88.

Frank, David A., and Mark Lawrence McPhail. "Barack Obama's Address to the 2004 Democratic National Convention: Trauma, Compromise, Consilience, and the (Im)Possibility of Racial Reconciliation." Rhetoric and Public Affairs 8.4 (2005): 571-94.

Franklin, V.P. Living Our Stories, Telling Our Truths: Autobiography and the Making of the African-American Intellectual Tradition. New York: Oxford UP, 1995.

Fraser, Carly. "Race, Post-Black Politics, and the Democratic Presidential Candidacy of Barack Obama." Souls: A Critical Journal of Black Politics, Culture, and Society 11.1 (2009): 17-40. Gaines, Ernest J. The Autobiography of Miss Jane Pittman. 1971. New York: Bantam, 1972. Gates, Henry Louis, Jr. The Signifying Monkey: A Theory of African-American Literary Criticism. New York: Oxford UP, 1988.

Harris, Fredrick. “Towards a Pragmatic Black Politics?” Souls: A Critical Journal of Black Politics, Culture, and Society 11.1 (2009): 41-49.

Harrison, Maureen, and Steve Gilbert, eds. Barack Obama: Speeches 2002-2006. Carlsbad: Excellent, 2007. 
Hill, Rickey. "The Race Problematic, the Narrative of Malcolm Luther King Jr., and the Election of Barack Obama." Souls: A Critical Journal of Black Politics, Culture, and Society 11.1 (2009): 60-78.

Hollinger, David A. "Obama, the Instability of Color Lines, and the Promise of a Postethnic Future.” Callaloo 31.4 (2008): 1033-37.

Hurston, Zora Neale. "How It Feels to Be Colored Me.” I Love Myself when I Am Laughing... and then again when I am Looking Mean and Impressive: A Zora Neale Hurston Reader. Ed. Alice Walker. New York: Feminist Press, 1975. 152-55.

James, Stanlie M. “Barack Obama: Coalitions of a Purple Mandate.” Souls: A Journal of Black Politics, Culture, and Society 11.1 (2009): 51-59.

Kelleter, Frank. Con/Tradition: Louis Farrakhan's Nation of Islam, the Million Man March, and American Civil Religion. Heidelberg: Winter, 2000.

---. "Ethnic Self-Dramatization and Technologies of Travel in The Interesting Narrative of the Life of Olaudah Equiano, or Gustavus Vassa, the African, Written by Himself (1789)." Early American Literature 39.1 (2004): 67-84.

Kelley, Robin D.G. Freedom Dreams: The Black Radical Imagination. Boston: Beacon, 2002.

King, Martin Luther, Jr. “I Have a Dream.” 1963. Daley 111-14.

Malcolm X, as told to Alex Haley. The Autobiography of Malcolm X. New York: Grove, 1965.

Marable, Manning. "Racializing Obama: The Enigma of Post-Black Politics and Leadership." Souls: A Journal of Black Politics, Culture, and Society 11.1 (2009): 1-15.

Mastey, David. "Slumming and/as Self-Making in Barack Obama's Dreams from My Father" Journal of Black Studies 40.3 (2010): 484-501.

Morrison, Toni, ed. James Baldwin: Collected Essays. New York: Library of America, 1998.

Obama, Barack. The Audacity of Hope: Thoughts on Reclaiming the American Dream. New York: crown, 2006.

---. “Democratic Nominee Acceptance Speech." Chicago 28 Aug. 2008. Rpt. Inspire a Nation: Barack Obama's Most Electrifying Speeches from Day One of His Campaign through His Inauguration. Ed. Jaclyn Easton. Publishing 180, 2009. 120-37.

---. Dreams from My Father: A Story of Race and Inheritance. 1995. New York: Crown, 2004.

---. "The Great Need of the Hour." Atlanta 20 Jan. 2008. Rpt. Olive 238-44.

---. "Keynote Address at the 2004 Democratic National Convention." Boston 27 July 2004. Rpt. Olive 98-104.

---. “A More Perfect Union.” Philadelphia 18 March 2008. Rpt. Olive 255-69.

---. "Remarks of President-Elect Barack Obama: Election Night." Chicago 4 Nov. 2008. Rpt. Olive $318-23$.

Ogbar, Jeffrey O.G. Black Power: Radical Politics and African American Identity. Baltimore: Johns Hopkins UP, 2004.

Olive, David, ed. An American Story: The Speeches of Barack Obama. Toronto: ECW, 2009.

Pinckney, Darryl. “Dreams from Obama.” New York Review of Books 55.3 (2008) <http:// www.nybooks.com/articles/21063>. 
---. “Obama and the Black Church." New York Review of Books. 55.12 (2008). <http:// www.nybooks.com/articles/21611>.

Posnock, Ross. Color and Culture: Black Writers and the Making of the Modern Intellectual. Cambridge: Harvard UP, 1998.

Rushdy, Ashraf H.A. Neo-Slave Narratives: Studies in the Logic of a Literary Form. New York: Oxford UP, 1999.

Samuels, David. "Invisible Man: How Ralph Ellison Explains Barack Obama." New Republic 22 Oct. 2008. http://www.tnr.com/politics/story.html?id=5c263e1d-d75d-4af9-a1d7-5cb761500092

Smallwood, Christine. "Back Talk: Toni Morrison." Nation 19 Nov. 2008. <http:// www.thenation.com/doc/20081208/smallwood2.>

Steele, Shelby. A Bound Man: Why We Are Excited about Obama and Why He Can't Win. New York: Free Press, 2008.

Stein, Daniel. “The Things that Jes' Grew? The Blues 'I' and African American Autobiographies.” Interdisciplinary Humanities 23.2 (2006): 43-54.

---. “Walter Mosley's RL's Dream and the Creation of a Bluetopian Community." Finding a Way Home: A Critical Assessment of Walter Mosley's Fiction. Ed. Derek C. Maus and Owen E. Brady. Jackson: UP of Mississippi 2008. 3-17.

Tóibín, Colm. “James Baldwin and Barack Obama.” New York Review of Books 55.16 (2008). http://www.nybooks.com/articles/21930.

Walters, Ron. "Barack Obama and the Politics of Blackness." Journal of Black Studies 38.7 (2007): 7-29.

Washington, Booker T. “Atlanta Exposition Address.” 1895. Daley 81-84.

West, Cornel. Keeping Faith: Philosophy and Race in America. 1993. New York: Routledge, 1994.

Wright, Richard. Black Boy: A Record of Childhood and Youth. New York: Harper's, 1945.

\section{NOTES}

1. For rhetorical analyses of earlier speeches, see Atwater; Frank and McPhail; for collections, see Easton; Harrison and Gilbert; Olive.

2. King exclaimed: "When the architects of our republic wrote the magnificent words of the Constitution and the Declaration of Independence, they were signing a promissory note to which every American was to fall heir. This note was a promise that all men would be guaranteed the unalienable rights of life, liberty, and the pursuit of happiness" (111-12). In his acceptance speech at the Democratic National Convention in 2008, Obama had already made use of King's speech, repeating the refrain "now is the time" ("Democratic" 128-29) and speaking of the "American promise" that has "brought Americans from every corner of this land to stand together on a Mall in Washington ... and hear a young preacher from Georgia speak of his dream" (136).

3. Ellison's understanding of history in Invisible Man is actually doubly coded. It includes the boomerang analogy and the idea that African American culture has established its own, creative way of dealing with history by transforming the national beat into a "groove of history" (335). Obama's allegiance, however, is more with King's "beautiful symphony of brotherhood" (114) than with Ellison's view of America as nation "always in cacophonic motion" ("Little Man" 504).

4. In "A More Perfect Union," Obama detected "complexities of race in this country that we've never really worked through" and identified the relations among the many ethnicities in the U.S. 
as "a part of our union we have yet to perfect" (260-61); in his victory speech, he declared: "Our union can be perfected" ("Remarks" 322).

5. Obama's conversion account carries faint traces of Ellison's sermon on the "blackness of blackness" in the prologue of Invisible Man but comes to a much more unambiguous conclusion.

6. The concept of the "audacity of hope" evokes what Cornel West has described as "the difficulty of keeping faith," which is grounded in "the love ethic of Christian faith" and inspires a "prophetic vision and practice" aimed at "keep[ing] alive a tempered hope for the future, a hope against hope that human empathy and compassion may survive against the onslaught of human barbarity, brutality and bestiality" (ix-xi). On Obama's thoughts on religion, see Dreams from My Father (chapter 14), Audacity of Hope (chapter 6), and "A More Perfect Union”; see also Pinckney, "Obama \& the Black Church."

7. On the connections between African American intellectual traditions and the genre of autobiography, see Franklin; on African American intellectuals, see Kelley; Posnock; West. Daley's Great Speeches by African Americans (2006) places Obama in a line of African American orators, including Sojourner Truth, Frederick Douglass, Booker T. Washington, W.E.B. Du Bois, Ida B. Wells, Marcus Garvey, Martin Luther King, and Malcolm X.

8. The phrase "black man with a funny name" may be read as a pun on the title of James Baldwin's essay "Nobody Knows My Name" (1961). Obama's interest in creating a public and politically productive self explains his overwhelming reliance on the writings of male writers; according to Philip Abbott and Shari Benstock, male American writers have tended to use autobiography as a platform for political ideas while women authors have often described more private selves.

9. For engagements with Obama's writings that are more explicitly critical than my own readings, see Banita; Mastey.

10. The father's death is a central event in the story; its depiction recalls Baldwin's essay "Notes of a Native Son" (1951), where Baldwin wrote: "When he was dead I realized that I had hardly ever spoken to him" (63). Obama notes: "At the time of his death, my father remained a myth to me" (5). One of the earliest autobiographical negotiations, indeed dramatizations, as Kelleter has argued, of a transatlantic identity is The Interesting Narrative of the Life of Olaudah Equiano, or Gustavus Vassa, the African (1789). See also Chinosole.

11. Stein elaborates on the significance of these themes in African American literature in "Walter Mosley's RL's Dream and the Creation of a Bluetopian Community." In Obama's discourse, the rhetoric of dreams-"the true genius of America" as the "faith in the simple dreams of its people" ("Keynote" 100)-includes a mixture of personal and political references: to his father's and grandfather's aspirations (cf. "Keynote" 98), to the dreams of the nation's founding founders (cf. "Remarks" 318), and to the notion of the "American Dream" (cf. "A More Perfect Union" 262; "Remarks" 323).

12. Samuels is much more skeptical when he writes that Dreams from My Father is "shot through with the vanity of a young man trying on borrowed clothing in front of a mirror as he attempts to figure out exactly what kind of black man he will be."

13. Crouch's title evokes John Howard Griffin's blackface experiment Black like Me (1962), and in this context, Obama's remark about the new White House puppy-“a mutt like me"-during his first press conference as president-elect comes across as a critical rejoinder to those who had questioned his racial pedigree. In "A More Perfect Union," Obama argued that he is connected indirectly with the history of American slavery through his daughters Malia and Sasha, whose mother Michelle has slave ancestors: "I am married to a black American who carries within her the blood of slavers and slaveowners-an inheritance we pass on to our two precious daughters" (256). On Obama as a simultaneously "post-black," "post-ethnic," and "racialized" politician, see Fraser; Hollinger; Marable. 
14. Cf. Andrews: "Autobiography holds a position of priority, indeed many would say preeminence, among the narrative traditions of black America" (1).Stein has argued that the genre of the slave narrative should be read in conjunction with the performative creation of public selves in the form of a "blues 'I," a first-person poetics communicating personal experiences autobiographically in media other than literature (see "The Things That Jes' Grew?"). The concept of the "blues 'I"' evokes the title of Toni Morrison's first novel Bluest Eye (1970); Obama establishes a connection with the novel in a scene that depicts his black friend "Ruby and her blue eyes" (Dreams 199).

15. Obama later expressed fondness for Toni Morrison's novels, especially Song of Solomon (1977). The novel's themes of African storytelling and the absent father resonate with the most lyrical passages in Dreams of My Father. The fondness is reciprocal; Morrison has called Obama "a writer ... with reflection and change and meditation and strength" and Dreams from My Father "a very, very compelling" book with "big, strong, artful sentences" (qtd. in Smallwood). Obama quoted the title and central phrase from Hughes's poem "Harlem: A Dream Deferred" (1951) in his acceptance speech at the democratic National Convention in 2008 ("Democratic" 136). On Obama and Hughes, see Pinckney, "Dreams"; on his indebtedness to Baldwin, see Tóibín.

16. The references are to Du Bois's emigration to Ghana, to Wright's emigration to France, and to Invisible Man's basement existence below the streets of Harlem.

17. Perhaps the most important lesson he learned from his mother is this: "To be black was to be the beneficiary of a great inheritance, a special destiny, glorious burdens that only we were strong enough to bear" (51).

18. Obama also immerses himself in "color-coded" popular culture: "I couldn't croon like Marvin Gaye, but I could learn to dance all the Soul Train steps. I couldn't pack a gun like Shaft or Superfly, but I could sure enough curse like Richard Pryor" (78). He eventually realizes that he is "living out a caricature of black male adolescence" (79) and decides "to give the bad-assed nigger pose a rest" (82). Obama's musical tastes come to include Billie Holiday, whose "willingness to endure" he learns to admire (112).

19. The passage to which Obama refers appears in chapter 12 of The Autobiography of Malcolm X: "You see me-well, in the streets they used to call me Detroit Red. Yes! Yes, that raping, redheaded devil was my grandfather! That close, yes! My mother's father! ... She said she never laid eyes on him! ... If I could drain away his blood that pollutes my body, and pollutes my complexion, I'd do it! Because I hate every drop of the rapist's blood that's in me" (203-04).

20. Eakin finds in The Autobiography of Malcolm X "an impressive, highly self-conscious awareness of the problems of autobiographical narrative, and specifically of the complex relationship between living a life and writing an autobiography" (159), but Obama focuses on Malcolm X's remarks about his racial heritage rather than "the incompleteness of the self" (160) presented in the narrative.

21. On the contrast between reconciliation and revolt in twentieth-century American history, see Cone; Kelley. Obama's statements about multiracialism, for instance the dismissive remark that people with multiple racial backgrounds "talked about the richness of their multicultural heritage and it sounded real good, until you noticed that they avoided black people" (99), have been criticized because they allegedly contradict his rhetoric of reconciliation. But these statements are made by the autobiographical character, who, at that point in the narrative, is a confused adolescent who has just been told by the black poet Frank that whites will always “'yank on your chain and let you know that you may be a well-trained, well-paid nigger, but you're a nigger just the same"' (97).

22. In the 2004 introduction, Obama downplays the focus on his father, writing that his mother had proofread the manuscript and made suggestions for revision. He further seeks to remedy her marginal role by evoking her "capacity for wonder" (xii) in a passage reminiscent of F. Scott Fitzgerald's closing words in The Great Gatsby (1925) and, after his mother's passing, by dedicating 
The Audacity of Hope to her and his grandmother as "the women who raised me" (n. pag.). David Dudley's study of intergenerational conflicts among black writers is a useful source in this context. Dudley notes that Douglass and Washington did not know their fathers and that Du Bois, Wright, and Malcolm X lost their father when they were young; he further detects "among these writers a kind of Oedipal conflict wherein each rising writer faces and overcomes his predecessor in the tradition ... of African American men's autobiographies" (1-2).

23. On the effectiveness of Malcolm X's ideas, he writes: "What in the hands of Malcolm had once seemed a call to arms ... came to be the very thing Malcolm had sought to root out: one more feeder of fantasy, one more mask for hypocrisy, one more excuse for inaction" (203). Obama also comments critically though cautiously on Louis Farrakhan and the Nation of Islam (cf. 87, 196, 201). On the black power ideology and the radical politics of the 1960s, which provide one context for the strain of black nationalism depicted in Dreams from My Father, see Ogbar; on the cultural politics and religious rhetoric of the Nation of Islam, see Kelleter. Obama's political pragmatism is discussed in Harris.

24. Samuels calls Dreams from My Father a "black male bildungsroman that also serves as a kind of autobiographical rejoinder to ... Ellison's Invisible Man."

25. Cf. Samuels: "Ellison's protagonist is invisible because the symbolic radiance of his black skin queers the efforts of others to relate to him as an individual, and makes him prey to the manipulations of whites and blacks alike who utilize the brutal and absurd dynamics of the color line to satisfy private lusts for power and domination.... Ellison's deeper point is that the symbolic and actual baggage of race makes it difficult if not impossible for a black man to ever realize his full humanity in the eyes of anyone-white, black, communist, capitalist, or himself." Obama makes an Ellisonian argument early in his narrative: "Blacks are there but not there, like Sam the piano player or Beulah the maid or Amos and Andy on the radio-shadowy, silent presences that elicit neither passion nor fear" (18).

26. This rejection finds precedent in Zora Neale Huston's "How It Feels to Be Colored Me" (1928), in which Hurston describes how she only feels "colored" because others perceive her that way and responds: "BUT I AM NOT tragically colored. There is no great sorrow damned up in my soul, nor lurking behind my eyes.... I do not belong to the sobbing school of Negrohood" (153).

27. The second section of Dreams from My Father ends with Obama's sister Auma suggesting that they travel to Kenya to see their grandfather's land and retrace their father's steps: “'We need to go home, Barack, and see him there"' (222). Note also how Obama connects the notion of invisibility with his role as a highly visible politician in The Audacity of Hope: "I serve as a blank screen on which people of vastly different political stripes project their own views" (11). This statement communicates an awareness of the paradoxes of race in American culture, the phrase "vastly different political stripes" alluding to the national flag and tying together notions of race, politics, and citizenship.

28. On the theory of literary "Signifyin(g)," see Gates. Ellison wrote in "The World and the Jug" (1964): "Being a Negro American ... imposes the uneasy burden and occasional joy of a complex double vision, a fluid, ambivalent response to men and events which represents, at its finest, a profoundly civilized adjustment to the cost of being human in this modern world" (177-78).

29. Posnock maintains that Du Bois actually "does not desire to dissolve his 'double self' into unitary identity. His priority is to resolve the paralysis of black agency ... by making it possible to be black and American" (90). Asante claims Obama for an Afrocentric interpretation: "To change one's situation, it is necessary to change one's consciousness. Obama's sense of agency is itself an Afrocentric act" (106).

30. In his speech on race, Obama argued that his diasporic story "has seared into my genetic makeup the idea that this nation is more than the sum of its parts-that out of many, we are truly one" ("A More Perfect Union" 256). In his presidential victory speech, he reiterated on "that fundamental truth-that out of many, we are one" (323); one of his most frequently repeated 
statements since his speech at the Democratic National Convention in 2004 was: "[T]here's not a liberal America and a conservative America-there's the United States of America. There's not a black America and white American and Latino America and Asian America; there's the United States of America" ("Keynote" 103). On Obama's potential as president to move beyond a black/ white dichotomy towards a "purple mandate," see James; on Ellison's earlier conceptualization of American pluralism as a culture of "motley mixtures," see Posnock 184-219.

31. Hill provides an extended assessment of Obama's connection with King's beloved community.

32. His experiences in Indonesia, where he lived for several years with his mother and stepfather and where, according to Samuels, he discovered "the global dimensions of the color line," may have prepared him for his journey into postcolonial Africa.

33. Baldwin had written: "I wanted to prevent myself from becoming merely a Negro; or, even, merely a Negro writer" ("Discovery" 137). Obama's autobiography marks its status as a text that performs a specific function for its author much more clearly than Samuels acknowledges when he criticizes that the narrator "hopes to become a whole, untroubled person" and "moves from triumph to triumph along the road to successfully embracing the fullness of his black identity." Cf. also Obama's references to the "useful fiction" of his father's stories (25) and the "selective memory" (178) of the black Chicagoans he tries to organize.

\section{ABSTRACTS}

This article provides a series of close readings of Barack Obama's autobiography Dreams from My Father. It places the narrative within the history of African American literature and rhetoric and argues that Obama uses the text to create a life story that resonates with central concepts of African American selfhood and black male identity, including double consciousness, invisibility, and black nationalism. The article reads Dreams from My Father as an attempt to arrive at a state of "functional Blackness," which moves away from questions of racial authenticity and identity politics but recognizes the narrative powers of African American literature to shape a convincing and appealing black self.

\section{INDEX}

Keywords: African-American, Autobiography, Black Nationalism, Consciousness, Double, Dreams from My Father, Functional Blackness, Invisibility

\section{AUTHORS}

\section{DANIEL STEIN}

Georg-August-Universität Göttingen 